\title{
Production of Antibacterial Substance(s) by a Bacterial Strain, E-14, Isolated from Rice Phylloplane
}

\author{
Kazuyuki Hirayae** and Satoshi Wakimoto*
}

Key words : phylloplane, bacteria, antibacterial substance(s).

Some antibiotics were known to be produced by saprophytic and plant pathogenic bacteria isolated from phylloplane or rhizosphere. The antibiotics pyoluteorin ${ }^{1}$ and pyrrolnitrin ${ }^{2)}$ were reported to be produced by some strains of Pseudomonas fluorescens ${ }^{3,4)}$ and tropolone ${ }^{5,6)}$ was produced by some strains of pseudomonad ${ }^{7,8)}$. The activity of these antibiotics against plant pathogenic bacteria and fungi were also reported by some workers. Bacteriocins ${ }^{9)}$ were also reported by many workers to be produced by plant pathogenic bacteria. Phytotoxins such as syringomycin and syringotoxin produced by $P$. syringae pv. syringae strains were also known to have antibiotic activity ${ }^{10,11)}$. Besides, many attempts to increase crop yield by means of biological control of the diseases using effective bacteria have been reported ${ }^{12-23)}$. Among these trials, one of the most distinguished achievements was biological control of the crown gall disease of dicotyledonous plants caused by Agrobacterium tumefaciens by application of $A$. radiobacter strain K84 producing Agrocin 84, a kind of bacteriocin ${ }^{15,18)}$.

To find out some bacteria producing antibiotics, 146 bacterial isolates were collected from phylloplane of 25 kinds of plants belonging to 12 families. For isolating bacteria

\footnotetext{
* Fuculty of Agriculture, Kyushu University, Fukuoka 812, Japan九州大学農学部

** Present address: National Institute of Agrobiological Resources, Tsukuba Science City, Yatabe, Ibaraki 305, Japan 現在：農林水産省農業生物資源研究所

1) Takeda, R. (1958). J. Am. Chem. Soc. $80: 4749-4750$. 2) Arima, K., Imanaka, H., Kousaka, M., Fukuda, A. and Tamura, G. (1965). J. antibiotics Ser. A 18 : 201-204. 3) Howell, C. R. and Stipanovic, R. D. (1979). Phytopathology $69:$ 480-482. 4) Howell, C. R. and Stipanovic, R. D. (1980). Ibid. $70: 712-715$. 5) Doering W. von E. and Knox, L. H. (1951). J. Am. Chem. Soc. $73: 828-838$. 6) Trust, T. J. (1975). Antimicrob. Agents Chemother. $7: 500-506$. 7) Lindberg, G. D. (1981). Plant Disease $65: 680-683.8$ 8) Azegami, K., Nishiyama, K., Watanabe, Y., Suzuki, T., Yoshida, M., Nose, K. and Toda, S. (1985). Ann. Phytopath. Soc. Japan $51: 315-317$. 9) Kerr, A. (1980). Plant Disease 64 : 25-30. 10) Sinden, S. L., DeVay, J. E. and Backman, P. A. (1971). Physiol. Plant Pathol. $1: 199$ -213. 11) Gross, D. C., DeVay, J. E. and Stadtman, F. H. (1977). J. Appl. Bact. 43: 453-463. 12) Burr, T. J., Schroth, M. N. and Suslow, T. (1978). Phytopathology $68: 1377-1383$. 13) Chen, W. Y., Echandi, E. and Spurr, H. W. (Jr) (1981). In Proc. Fifth Int. Plant Path. Bact., Cali, Colombia, pp. 482-492. 14) Chen, W. Y. and Echandi, E. (1984). Plant Pathology $33: 245-253$. 15) Cooksey, D. A. and Moore, L. W. (1980). Phytopathology $70: 506-509$. 16) Howie, W. J. and Echandi, E. (1983). Soil Biol. Biochem. $15: 127-132$. 17) Hsieh, S. P. Y. and Buddenhagen, I. W. (1974). Phytopathology 64 : 1182-1185. 18) Htay, K. and Kerr, A. (1974). J. Appl. Bact. $37: 525-530$. 19) Kemp, J. and Sequeira, L. (1983). Plant Disease $67:$ 499-503. 20) Kloepper, J. W. (1983). Phytopathology $73: 217$ -219. 21) Kloepper, J. W. and Schroth, M. N. (1981). Ibid. $71: 1020-1024$. 22) Lindow, S. E., Arny, D. C. and Upper, C. D. (1983). Ibid. $73: 1097-1102.23)$ Suslow, T. V. and Schroth, M. N. (1982). Ibid. $72:$ 199-206.
} 
from phylloplane, PSA medium (decoction of potato $300 \mathrm{~g} /$ liter 1 liter, $\mathrm{Na}_{2} \mathrm{HPO}_{4} \cdot 12 \mathrm{H}_{2} \mathrm{O}$ $2 \mathrm{~g}$, $\mathrm{Ca}\left(\mathrm{NO}_{3}\right)_{2} \cdot 4 \mathrm{H}_{2} \mathrm{O} 0.5 \mathrm{~g}$, peptone $5 \mathrm{~g}$, sucrose $20 \mathrm{~g}$, agar $15 \mathrm{~g}, \mathrm{pH} 7.0$ ) was used. From spring to autumn of 1980, the leaves of various plants were collected from various localities in Fukuoka Prefecture. The leaves were cut into small pieces by scissors to put them into test tube. After the addition of sterilized distilled water, the tube was shaked strongly, and the supernatant was streaked on the plate of PSA medium. The plate was then incubated at $30 \mathrm{C}$ for 24 to $96 \mathrm{hr}$. By this method, 206 bacterial strains were obtained. Among these strains, the spore forming bacteria were discarded from this experiment because they survive even after chloroform treatment which is the necessary procedure for testing productivity of antibacterial substances effective against plant pathogenic bacteria. The bacteria used as indicator were A.tumefaciens, Corynebacterium michiganense pv. michiganense, $P$. solanacearum, P. syringae pv. syringae, Xanthomonas campestris pv. citri and $X$. campestris pv. oryzae.

The productivity of antibacterial substance was detected as follows ${ }^{24)}$. The culture of each bacterial strain grown on the slant of PSA medium at $30 \mathrm{C}$ for $24 \mathrm{hr}$ was spot inoculated on the plate of YPDA medium (peptone $0.6 \mathrm{~g}$, yeast extract $3 \mathrm{~g}$, dextrose 3 $\mathrm{g}$, agar $15 \mathrm{~g}$, distilled water 1 liter, $\mathrm{pH} 7.2$ ) and incubated at $30 \mathrm{C}$ for 24 to $48 \mathrm{hr}$ until the bacteria grew up into colonies of ca. $5 \mathrm{~mm}$ in diameter. The Petri dish thus prepared was placed upside down, a filter paper was sheeted in the lid, and chloroform (1.5 $\mathrm{ml}$ ) was poured on the filter paper to kill bacteria by its vapor. The plate was then overlaid with $0.1 \mathrm{ml}$ of the suspension of indicator bacteria (conc., ca. $10^{8}$ cells $/ \mathrm{ml}$ ) mixed with $5 \mathrm{ml}$ of YPDA (0.5\% agar) medium at $45-47 \mathrm{C}$. The plate was incubated at $30 \mathrm{C}$ for 24 to $48 \mathrm{hr}$, and the productivity of antibacterial substance(s) was detected by the formation of inhibition zone around colony. The antibacterial activity was determined by measuring the size of inhibition zone (Fig. 1).
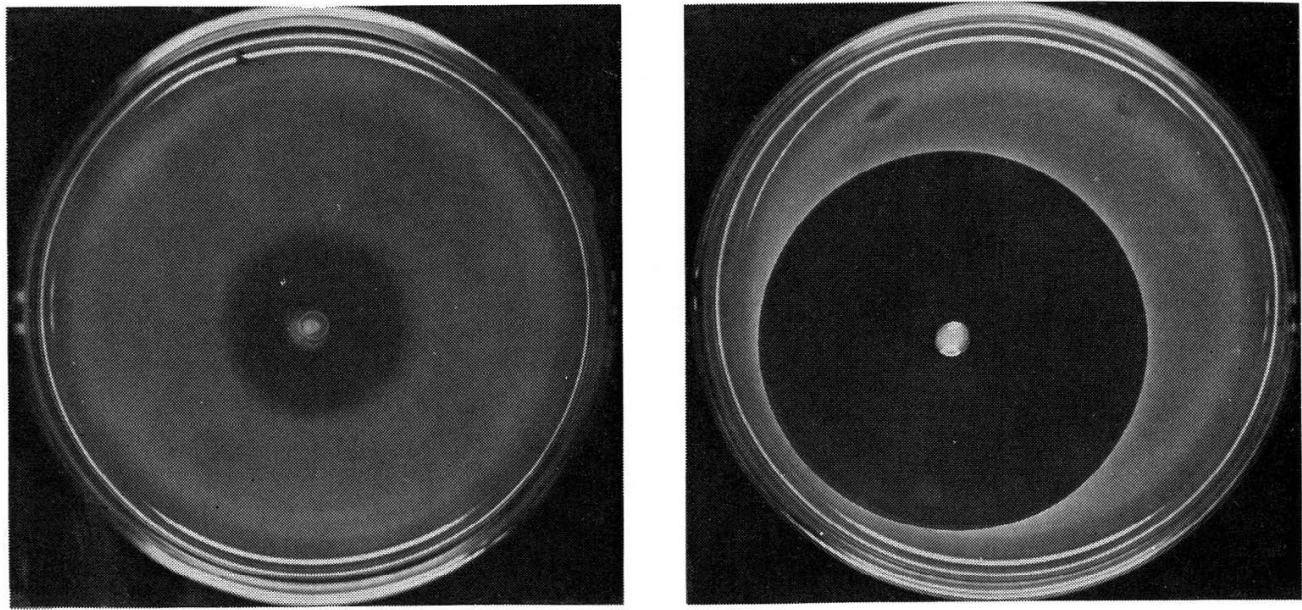

Fig. 1. Inhibtion zones formed on the lawn of indicator bacteria by the bacterial strain $\mathrm{E}-14$

Indicators were Xanthomonas campestris pv. oryzae (left) and Corynebacterium michiganese pv. michiganense (right).

24) Fredericq, P. (1957). Ann. Rev. Microbiol. $11: 7-22$. 
Table 1. Antibacterial spectra of the substance(s) produced by the bacterial strain E-14

\begin{tabular}{|c|c|c|c|}
\hline \multirow[b]{2}{*}{ Indicator bacteria } & \multicolumn{3}{|c|}{ Activity } \\
\hline & $\begin{array}{l}\text { shown by the } \\
\text { plate chloro- } \\
\text { form method }{ }^{b}\end{array}$ & $\begin{array}{l}\text { of the culture } \\
\text { filtrate }^{c)}\end{array}$ & $\begin{array}{l}\text { of the exudate } \\
\text { from agar } \\
\text { medium }{ }^{\text {s) }}\end{array}$ \\
\hline Agrobacterium tumefaciens $\mathrm{Ku} 7411$ & H & - & - \\
\hline Corynebacterium michiganese & $W^{*}$ & 卅* & H \\
\hline pv. michiganense N6601 & & & H \\
\hline C. michiganense pv. sepedonicum Ku7602(a) & $\mathrm{W}^{*}$ & H* & - \\
\hline Erwinia carotovora subsp. carotovora N7129 & H & - & - \\
\hline Pseudomonas avenae $\mathrm{H} 8205$ & H & - & - \\
\hline P. glumae N7501 & \pm & - & - \\
\hline P. solanacearum $\mathrm{KT}-2$ & H & - & - \\
\hline P. syringae pv. syringae I & H & - & + \\
\hline Xanthomonas campestris pv. citri N6113-1 & H & - & H \\
\hline$X$. campestris pv. oryzae $\mathrm{T} 7174$ & H & - & $H$ \\
\hline
\end{tabular}

a) : - not detected, \pm faint activity, \# 5-10 $\mathrm{mm}$, \# 10-15 $\mathrm{mm}$, H* above $20 \mathrm{~mm}$ in the size of inhibition zone.

b) : The bacterium was spot inoculated on YPDA plate and cultured for $36 \mathrm{hr}$ at $30 \mathrm{C}$, treated with chloroform vapor, and overlaid with indicator bacteria.

c) : Shake cultured in YPD liquid medium for $72 \mathrm{hr}$ at $30 \mathrm{C}$.

d) : YPDA medium on which the producer was grown for $36 \mathrm{hr}$ at $30 \mathrm{C}$, was frozen at -20 $\mathrm{C}$, and thawed at room temperature to obtain exudate.

Among 146 strains, 3 were active against A. tumefaciens, 22 against C. michiganense pv. michiganense, 5 against $P$. solanacearum, 8 against $P$. syringae pv. syringae, 9 against $X$. campestris pv. citri and 12 against $X$. campestris pv. oryzae. No relationships were observed between productivity of antibacterial substance(s) and kind of plants from which the bacteria were isolated. Among these bacteria producing antibacterial substance(s), the strain E-14 obtained from leaf surface of a healthy rice plant showed widest antibacterial spectrum (Table 1) producing clear inhibition zones (Fig. 1).

The strain E-14 was active not only against all of the six bacteria used as indicator but also against $C$. michiganense pv. sepedonicum, Erwinia carotovora subsp. carotovora and $P$. avenae (Table 1). The strain produced largest and clearest inhibition zone of the lawn of $C$. michiganense pv. michiganense and C. michiganense pv. sepedonicum. Large and clear inhibition zone was also observed on the lawn of $X$. campestris pv. oryzae and pv. citri.

The productivity of antibacterial substance(s) in liquid medium was also examined under shaking and still culture conditions. The samples obtained periodically were sterilized by filtration through Millipore filter $(0.2 \mu \mathrm{m})$ and the activity was evaluated by paper disk method. To find out more efficient method for obtaining antibacterial substance(s), the exudate obtained by freezing ( $-20 \mathrm{C}$, for above $2 \mathrm{hr}$ ) and thawing (room temperature, $2 \mathrm{hr}$ ) of the culture plates was also evaluated ${ }^{25}$.

As shown in Table 1, the filtrate of YPD liquid culture showed antibacterial activity only against corynebacteria, and the exudate form culture plates showed activity against corynebacteria and xanthomonads. In the case of liquid culture filtrate, the highest ac-

25) Jetten, A. M., Vogels, G. D. and de Windt, F. (1973). J. Bacteriol. 112:235-242. 
tivity against $C$. michiganense pv. michiganense was shown at 72 to $96 \mathrm{hr}$ of incubation under shaking condition and at 96 to $144 \mathrm{hr}$ under the still culture condition. When the producer was streaked all over surface of YPDA plate, the exudate obtained at 24 to $48 \mathrm{hr}$ of incubation showed highest activity against both corynebacteria and xanthomonads.

Thus, the strain E-14 showed different activity range depending upon its culture conditions, suggesting that the isolate can produce several kinds of antibacterial substance.

The strain E-14 was identified as a kind of pseudomonads and its characteristics will be published elsewhere in detail.

\section{和 文 摘 要}

\section{平八重一之・脇本 哲：イネ葉面汃ら分離した細菌株 E-14 の抗菌物質産生性}

植物病原細菌の生物的防除隹有効な細菌株を得る目的で，25種類の植物の表面から分離した細菌 146 菌株を 供試し, 重要植物病原細菌を指示菌としてそれらの抗菌物質産生性を調査した。その結果, 供試した細菌分 離株のうち，イネから得た E-14 株が最む厸い抗菌スペクトラムを示すととが明らかとなった。E-14 株は YPDA 培地上で生育させたコロニーをクロロホルム蒸気で処理して指示菌を重層したとき，卜マトかいよう 病菌抢よびジャガイモ輪腐病菌に対して最も大型の阻止帯を形成し，イネ白葉枯病菌，カンキツかい上う病菌 等に対しても大型の阻止帯を形成した。YPD 液体培養汇液にはトマトかいよう病菌およびジャガイモ輪腐病 菌に対する活性のみが認められ，YPDA 平板培養の凍結融解渗出液には，乙れら両指示菌の他，イネ白葉枯 病菌执よびカンキツかいよう病菌に対する活性屯認められた。 